\title{
COMMENT
}

\section{SHOULD THE RATE MAKING UNIT BE FIXED BY STATUTE?}

\author{
E. G. BAIRD*
}

TN THE early days of utility regulation the municipality was the area of operation of the average public service company. The typical plant was a locally owned and operated corporate entity seldom serving more than the one community. In consequence the municipality became first in fact the basic unit of rate regulation. Rates were fixed by contract and ordinance. The early statutes recognized this essentially local character of utility operations, and commonly authorized the municipalities to regulate rate and service matters within their borders. With the subsequent development of utility service came the statutes creating state regulatory commissions or authorizing the older warehouse and railroad commissions to deal with the utility enterprises. These statutes commonly provided for hearings upon complaint of a municipality or a specified number of residents. In addition many of these statutes prohibited utility companies from granting or maintaining undue preferences or advantages in rates in one locality to the prejudice of other localities. Schedule making retained its local significance, tariffs being commonly devised for application to particular towns and cities. Thus has rate making retained an essentially local characteristic.

The statutes remain generally unchanged, although time has brought the widespread utility companies serving many towns and cities even across state boundaries, with a host of attendant difficulties in the evaluation of property, in revenue, expense and plant segregations and apportionments and in the distribution of the price burden itself. To meet the situation commissions have used two methods of calculating the fair return $^{x}$ to which utility management is constitutionally entitled and im-

* Professor of Law, The Hartford College of Law.

I States are without authority to determine the reasonableness of the total return of interstate companies. In Smith v. Illinois Bell Tel. Co., 282 U.S. 133, 148-49, 5I Sup. Ct. 65, 68-69 (1930) the Court said, per Mr. Chief Justice Hughes:

"The separation of the intrastate and interstate property, revenues and expenses of the company is important not simply as a theoretical allocation to two branches of the business. It is essential to the appropriate recognition of the competent governmental authority in each field 
posing that amount upon the consumers throughout the area served in the form of rates and charges. These methods were described by the New York Public Service Commission as follows:

. . . . This 'Iocal area' theory requires that telephone rates in any particular municipality shall be based on the company's investments in wires, apparatus, etc., utilized within the boundaries of that municipality.

Another method, known as the 'company wide' theory, requires the fixing of rates based on a valuation of the company's entire property; the determination of proper and necessary expenses, and the amount of revenues requisite to meet these expenses. Under this method, the payment of this revenue is distributed over all the company's various exchanges, in just proportions, according to the class of service desired, the number of subscribers, and the physical, industrial, commercial, social, business and residential needs and conditions. ${ }^{2}$

The "company-wide" method has been urged'as a principle of rate making since Smyth v. Ames. ${ }^{3}$ Applications of that method have been so common that some commissions and one court have clothed the proposition with the dignity of an established principle of administrative law. ${ }^{4}$ At

of regulation .... the interstate tolls are the rates applicable to interstate commerce, and neither these interstate rates nor the division of the revenue arising from interstate rates was a matter for the determination either of the Illinois Commission or of the court in dealing with the order of that Commission."

And see to the same effect: Florida v. United States, 282 U.S. I94 ( $x_{93}$ r); United Fuel Gas Co. v. Railroad Comm., 278 U.S. 300,49 Sup. Ct. $15 \circ$ (r929); New York v. United States, 257 U.S. 59r, 42 Sup. Ct. 239, 66 L. Ed. 385 (I922); Railroad Comm. of Wisconsin v. C., B. \& Q. R. R. Co., 257 U.S. $563,579,580,42$ Sup. Ct. 232, 234, 66 L. Ed. 37 I, 379, 380 (I922); Illinois Central R. R. Co. v. Public Util. Comm., 245 U.S. $493,507,508,38$ Sup. Ct. $x 70,175,62$ L. Ed. 425, 437 (rgr8); C., B. \& Q. R. R. Co. v. Railroad Comm. of Wisconsin, 237 U.S. 220, 35 Sup. Ct. 560, 59 L. Ed. 926 (I9r5); Houston, E. \& W. Texas Ry. Co. v. United States, 234 U.S. 342,34 Sup. Ct. 833,58 L. Ed. $x_{341}$ (rgr4); The Minnesota Rate Case, 230 U.S. 352, 434436, 33 Sup. Ct. 729, 57 L. Ed. I5 I I (rgr2); Western Union Tel. Co. v. Kansas, 216 U.S. I, 30 Sup. Ct. Igo, 54 L. Ed. 355 (I9I0).

2 Re New York Tel. Co., (N.Y.) P.U.R. 1922A, 497, 499. Blakeslee, Commissioner.

3 I69 U.S. 466, 54I, 18 Sup. Ct. 4I8, 432 (1898). Mr. Justice Harlan: "The argument that a railroad line is an entirety; that its income goes into, and its expenses are provided for, out of a common fund; and that its capitalization is on its entire line, within and without the State, can have no application where the State is without authority over rates on the entire line, and can only deal with local rates. ...."

4 For the commission decisions, see text, post. Michigan Bell Tel. Co. v. Odell, 45 F. (2d) I80 ( 1930 ) is the court case referred to. At pages $I 8 I-I 82$ the court said:

"The separable contention of the city of Detroit that . . . the property, revenues, and expenses of the plaintiff involved in the furnishing of telephone service in that city should be segregated from those involved in connection with the other exchanges in the state, . . . was held by the master to be contrary to established law on this subject, for the reason that, in determining whether rates prescribed by a state for a public utility are confiscatory, the property, revenues, and expenses of such utility ought to be considered on a state-wide basis. With this conclusion we agree. ...."

The case was remanded on motion for re-reference to the master for further hearings in view of the subsequent decision of the Supreme Court in Smith v. Illinois Bell Tel. Co., supra, note I, 282 U.S. 133,5 I Sup. Ct. 65 (I930). 
the other extreme is a legislature which has sought to prevent rate differentials as between contiguous cities served by the same company, and prescribed such regional situations as appraisal units in the fixing of electric rates. ${ }^{5}$

It is submitted that choice of rate making method is fundamentally a matter for administrative discretion in the specific instance. This discretion should not be controlled by statute. The commission and court opinions to be examined herein should not be interpreted as establishing either the local-area or the company-wide method as matter of law. Those decisions which require specific application of the local-area method should not be regarded as precluding the use of the company-wide method. This paper has no quarrel with methods. It seeks to challenge only the reasoning of those who have mistaken mere fact-finding for legal principle.

\section{THE COMMISSION AND COURT OPINIONS}

Under the former Michigan statute the commission was empowered to fix rates only upon a petition from city and company to compromise preceding negotiations. ${ }^{6}$ Rate making was purely a matter of local concern in the ordinary situation. Nevertheless in Re City of Pontiac the commission applied the company-wide method in evaluating the property and determining heating standards for a gas company which served two other communities not parties to the proceeding. The commission said that it would be practically impossible to segregate values as between the communities affected without the use of estimates and percentages which "would lead to theoretical refinements" and could "result in no good purpose." Therefore it fixed rates and a heating standard for Pontiac which the commissioners believed would be "appropriate" also for the other two towns.

The New York commission's opinion already referred to, pointedly illustrated the economies of time and expense the company-wide method allowed over the use of the local-area theory, saying:

In the Buffalo case it was necessary to appraise an office building in New York city, over 400 miles from the Buffalo local area, because executive, supervising and accounting work is carried on there for the entire company, and so is of benefit to the Buffalo local area. The percentage finally arrived at, of these various services, 2.3 per cent, was then applied to the valuation of the building and charged to Buffalo. A garage

5 Mich. Comp. Laws (rg29). $\S$ I Iogg is to the effect that where the same rate for electric service prevails or is fixed to apply in two or more contiguous cities served by the same company, the territory so served must be treated as a unit for the purpose of fixing rates and the rate not changed "until it shall be shown that continuation of such identical . . . . rate or rates will work substantial hardship to some municipality or person, firm or corporation affected thereby." Quoted at length in note 44 , post.

'Mich. Public Acts of igrg, 4 rg. 7 P.U.R. 1923D, 193, 216-218 (Mich.). 
and shop, the Seneca Office Building (used for offices of the western district of the company), and the cost of all the general telephone equipment in the western district, had to be so apportioned. Carrying these computations to the extent of their separation into exchange and toll property, and into exchange and toll use, gives an idea of the expense involved and is only one phase of the inquiry following the theory used. The financial benefit to the experts and attorneys engaged may be considerable, but the ultimate cost to the telephone subscriber and the taxpayer is an unnecessary burden. ${ }^{8}$

The Georgia commission adopted the company-wide method for the reason that "There is such inter-relation and interchange of service between the different local exchanges as prevents a separate treatment of each." The commission remarked further:

... The physical plant in Atlanta or Macon or Valdosta is used in part and to an extent by șome other exchanges in these immediate sections and hence it is an exceedingly difficult task to ascertain the strictly local uses of the properties involved and the values thereof, as well as a fair allocation of revenues and expenses. The greater the development in the state as a whole, the greater the value of the service to the individual community or subscriber, regardless of location or the character of the service contracted for.?

The Montana commission reviewed the practice of other commissions and came to the conclusion that "the state-wide method of treatment is now so universally adopted by courts and commissions that argument for it, as an original proposition is unnecessary." The commission also thought that accurate valuation of property within and apportionable to any particular local area or community would be impossible. ${ }^{\text {. }}$

In Oregon the Public Service Commission said:

... . The value to all telephone users of extension of service to many small com'munities, where the local expenses are necessarily greater than the local earnings, is so great that it is just and right that the state system be considered as a whole, such rates being fixed as will meet the entire cost, and the charges so distributed that uniform rates will prevail in exchanges of approximately the same size and development. ${ }^{\mathrm{rr}}$

This doctrine appears in the decision of the New York commission previously quoted from. That commission said:

If return be based solely on local investment, no company can develop unprofitable territory or extend telephone service to smaller communities. The measure of value of

${ }^{8}$ P.U.R. 1922A, 497, 501, sutpra, note 2. See also Re New York Tel. Co., P.U.R. 1930C, 325 , 366-367 (N.Y.). The Buffalo case referred to is Stone v. New York Tel. Co., and Farmer v. Same, P.U.R. I92ID, 736 .

${ }^{9}$ Re Southern Bell Tel. \& Tel. Co., P.U.R. I92IC, 833, 849. By the Commission.

so Public Serv. Comm. v. Mountain States Tel. \& Tel. Co., P.U.R. I924C, 545, 556.

II Re Pacific Tel. \& Tel. Co., P.U.R. I922C, 248, 272. By the Commission. Cf. Re Pacific Tel. \& Tel. Co., P.U.R. I920B, r99. 
telephone service to a subscriber is based upon the most complete extension of telephone service..$^{\mathrm{Iz}}$

The same point of view was expressed by the Pennsylvania commission, the company-wide method being carried to the point where a local segregation and apportionment for the purpose of testing the reasonableness of local service rates was denied a petitioning municipality. The commission had used the company-wide method in valuing the property of the Bell Company throughout the state, rates for particular cities being fixed upon a consideration of factors similar to those mentioned by the New York commission in the quoted case. Cities were grouped into divisions or groups according to telephonic population, the largest cities of the first group thus paying the highest charges, the smaller cities in the second group paying slightly lower charges, the smallest communities in the last group paying the lowest charges of all. In no case was the revenue obtained from a particular city related to a segregated valuation of the property used and useful in that city, that test for adequacy in return being applied only to the total statewide return. The city of New Castle petitioned for a reopening of the statewide case, arguing that the reasonableness of local rates could only be determined by an evaluation of the company's property in and apportionable to that city. The commission in denying this contention said that such a procedure in fixing rates would require over four hundred separate valuations in the state of Pennsylvania and hinted that an application of the local-area theory might have a result unfavorable to the city of New Castle. The commission said further:

It is well known that the present theory of telephone rate making is based upon making the cost of service to subscribers correspond to the amount of service which is at their command. Thus the rates in this state are greater in Philadelphia and Pittsb urg, in which large centers subscribers have the advantage of service embracing many thousands of subscribers, and the rates gradually reduce to the lowest charges, which are applied to exchanges having the fewest subscribers and, therefore, the most limited service.

It is entirely conceivable that if a theory such as that for which the city of New Castle contends . . . . should prevail, a great many of the smaller communities of the state, and possibly all of the rural districts, would be cut off entirely from telephone service by prohibitive rates. ${ }^{\mathrm{x}}$

In a subsequent case the company contended that it was entitled to earn a fair return upon the property used and useful in rendering service within a particular municipality. The commission denied this contention also. No segregation of property values and expenses had been submitted

12 P.U.R. 1922A, 497, 502, supra note 2.

${ }^{13}$ City of New Castle v. Bell Tel. Co., P.U.R. I92rB, 378, 380. By the Commission. 
in evidence by the company. The commission said that such evidence "would, however, be of little, if any, probative value." ${ }_{4}$

The New York, Montana, Oregon, and Pennsylvania statutes prohibit undue preferences between localities and between classes of service. ${ }^{15}$ Nevertheless these commissions found no difficulty in choosing the company-wide method and valuing the total intrastate property of a telephone utility as the unit for rate making purposes. Indeed, the Pennsylvania commission went farthest and actually denied the city of New Castle a statutory right to insist upon a local valuation.

It is clear that the commissions quoted were proceeding upon the theory that a utility company may not be permitted to charge rates in each of the municipalities it serves which will yield a profit over the costs of operations therein. Particular communities, under this theory, need not contribute a fully compensatory share to the state-wide return as a whole and indeed some of the language used would intimate that certain communities must even be served at a loss provided only that the companywide return as a whole is not reduced below the constitutional minimum. Whether the fixing of rates at less than cost in a favored group of smaller and less prosperous communities would violate any constitutional right upon which the company might insist would depend first, of course, on whether remunerative rates could be collected in such communities, and secondly, upon the application of general rate making principles enunciated by the United States Supreme Court. Should the rate schedule made to apply only to the various services rendered a particular group of cities cover the separable costs of these services and some "proper" share of the

${ }^{{ }^{4}}$ Long v. Lehigh Tel. Co., P.U.R. I927A, 772, 776. And see also United Business Men's Assn. v. Bell Tel. Co., (Pa.) P.U.R. r920F, 682.

Is N.Y. Cahill's Consol. Laws (I923); c. 49, §9I (telegraph and telephone companies); N.Y. Cahill's Consol. Laws (1930), c. 49, $\$ \$ 3^{2}$ (carriers), 65 (3) (gas and electric companies), 79(3) (steam companies), 9I (3) (telephoné and telegraph companies); Mont Rev. Code (I92I), $\S 3899$ (all utilities); Ore. Code (I930), $\$ \S 6 \mathrm{I}-265$ (all utilities), 62-r54 (carriers); Pa. Stat. (I920), § r8099 (all utilities). To the same effect are: Ariz. Rev. Code (r928), §679 (all utilities); Cal. Gen. Laws (I93I), Act 6386, $\S$ I9 (all utilities); Colo. Comp. Laws (I92 I), $\$ 2929$ (all utilities); Fla. Comp. Gen. Laws (I927), $\$ 6366$ (telephone and telegraph companies); Idaho Ann. Code (1932), $\$ 59-315$ (all utilities); Ill. Cahill's Rev. Stat. (r929), c. Irra, par. 53 (all utilities); Ky. Carroll's Stat. (Baldwin's Revision, r930), § 20re-r r (all utilities); Mich. Comp. Laws (I g29), §II704 (telephone companies only prohibited from discriminating between localities-Comp. Laws [rgr5], § 6693); Ohio Gen. Code Ann. (Page, I926), §6r4-I5 (all utilities); Miss. Ann. Code (r930), $\$ 7096$ (carriers, express and telephone and telegraph companies).

${ }^{26}$ To say that a certain service "costs" so much to render is to assume that it does. What is meant is that, so far as can be determined, a particular service causes certain expenditures to be made. Some of these expenditures can be accurately ascertained or pointed to as being directly and entirely caused by the particular traffic or service classification. These expenses are com- 
joint costs and yield some profit over, there would seem to be no constitutional invalidity, on the authority of Vandalia Railroad Company $v$. Schnull..$^{7}$ That case involved the validity of particular rates fixed upon but a few classes of freight and for transportation between certain points within the state of Indiana. The carrier contended that the revenue from a traffic to which a rate applies is the test of its legality, and that any deficiency in that revenue cannot be made up, over the company's objection, from the yield of rates on other traffic. Defendants in error contended that if the revenues from all of the intrastate business of the carrier were sufficient to compensate the company, particular rates though unremunerative, were nevertheless legal. Although the Court divided five to four in denying this latter contention, the case has never been over-ruled. It may be urged that the group method of fixing telephone exchange rates does not make the services rendered within any one city or within any one group of cities an "entire" traffic in the sense that term has been used by the Supreme Court. It may not be improper to regard these particular local services as parts only of one entire company-wide exchange service. If so, it is the revenue from the entirety which will determine constitutionality. The fact that subscribers to this service pay different rates the differentials being based upon the size of the town or city in which they live goes not to constitutionality but to the statutory question of unjust

monly referred to as "out of pocket" costs or "separable" costs. Other expenses which are not separable, in the sense that it cannot be determined with accuracy exactly what portion thereof any particular traffic or service classification is responsible for, are described as "overhead" costs or "joint" costs. In the text above "cost" means the sum of a traffic's separable expense and some more or less arbitrary share of the joint expenses. This is the definition insisted upon by the United States Supreme Court. In Northern Pacific Ry. Co. v. North Dakota, 236 U.S. 585,35 Sup. Ct. 429 , 59 L. Ed. 735 ( (91 $_{5}$ ), a particular rate on the transportation of lignite coal in carload lots was held invalid and confiscatory although under it the traffic produced revenue sufficient to cover its separable cost, because the revenue did not cover also a "proper" share of the overhead expenses and permit the carrier a substantial profit. The rule is well settled by the subsequent decisions of the Supreme Court. See Norfolk \& W. Ry. Co. v. Conley, 236 U.S. 605, 35 Sup. Ct. 437, 59 L. Ed. 745 (I9I5); Banton v. Belt Line Ry. Corp., 268 U.S. 4I3, 45 Sup. Ct. 534, 69 L. Ed. 1020 (x925); Chicago, M. \& St. P. Ry. Co. v. Public Util. Comm. of Idaho, 274 U.S. 344,47 Sup. Ct. 604, 7r L. Ed. 1085 (19I7); Ann Arbor R. R. Co. v. United States, 28I U.S. 658, 50 Sup. Ct. 444 (1930). See R. L. Hale, Non-Cost Standards in Rate Making, 36 Yale L. Jour. 56 (1926); Raymond T. Bye, Social Welfare in Rate Making, 32 Pol. Sci. Quar. 522 (IgI7). See also comments and notes: ${ }_{3}$ Mich. L. Rev. 676 (1915); 15 Col. L. Rev. 44I (IgI5); 28 Harv. L. Rev. 683 (r915); 63 Univ. Pa. L. Rev. 55I (rgr5); I So. L. Quar. 56 (I9I5); 23 Jour. Pol. Econ. 389 (r9I5). Cf. Groesbeck v. Duluth, South Shore \& Atl. Ry. Co., 250 U.S. 607 (rgrg), the effect of which was to require a rate above the cost on day coach passengers in order to permit the carrier to make up losses incurred in rendering dining car, sleeping car and parlor car services.

${ }^{17} 255$ U.S. II3, 4I Sup. Ct. 324 (x921). 
discrimination, which is a matter for local interpretation. A final answer to this suggestion must await a decision of the United States Supreme Court.

There is no doubt but that the company-wide method is in vogue in a majority of the states, irrespective of the terms of the regulatory statutes. ${ }^{\mathrm{r}}$ How far the use of the method is to be carried cannot be determined with accuracy, although it appears that the Pennsylvania commission has carried it to the extent of denying both city and company any right to insist upon local segregations and apportionments in telephone rate making.

On the other hand the Michigan Utilities Commission once took the view that the local-area method may upon occasion be preferred to the company-wide method. In Re Michigan State Telephone Company ${ }^{\mathrm{I} 8 \mathrm{a}}$ the commission reversed an earlier order approving rate schedules scaled to

${ }^{28}$ Alabama: Public Serv, Comm. v. Birmingham Elec Co., P. U. R. 1932D, I48. But see City of Birmingham v. Southern Bell Tel. Co., P.U.R. rgrgB, 79r.

Colorado: Re Mountain States Tel. \& Tel. Co., 3 Colo. P.U.C.R. I22, 322, quoted in Public Serv. Comm. v. Mountain States Tel. \& Tel. Co., P.U.R. I924C, 545, 557-558. But see Re Mountain States Tel. \& Tel. Co., P.U.R. x920C, 549 (I920).

Connecticut: Re New Haven Water Co., P.U.R. x932E, 97. The company's property was described as "physically so unified that ...." it was "impossible to make an allocation of the physical property to the various towns and the city served."

Illinois: Re Chicago \& W. Towns R. Co., P.U.R. rgrgA, 268; Re East St. Louis \& Suburban Ry. Co., P.U.R. IgrgE, 9r6. But see Re Illinois Northern Utilities Co., P.U.R. I920D, 979, IOI7.

Indiana: Re Indiana Bell Tel. Co., P.U.R. ${ }_{924} \mathrm{~A}$, I. But see post pages $46 \mathrm{I}-62$ and cases cited.

Louisiana: Ex parte Southern Bell Tel. \& Tel. Co., P.U.R. í29E, 392.

Maryland: Public Serv. Comm. v. Chesapeake \& Potomac Tel. Co., P.U.R. 1925B, 545 (r924).

Michigan: Re Michigan State Tel. Co., P.U.R. IgI8C, 8I; Re Citizens Tel. Co. of Grand Rapids, P.U.R. I92IE, 308. But see Re Michigan State Tel. Co., P.U.R. I922E, 584, 585-587; Re Dowagiac Tel. Co., P.U.R. x924C, r39, r4r.

Missouri: The position of this state is in doubt. The company-wide method was used in Re Green Light \& Power Co., Cases Nos. 227I-2286, Mo. P.S.C., Nov. I2, 1920, not reported in Public Utilities Reports, and the commission's decision was affirmed in State $e x$ rel. City of Harrisonville v. Public Serv. Comm., 29I Mo. 432, 236 S.W. 852 (1922). And see Re United Ry. Co., P.U.R. r919F, 264.

New Hampshire: Re New England Tel. \& Tel. Co., P.U.R. I926E, 186; Re Portsmouth Elec. Ry. Co., P.U.R. I9xgE, 266.

New Jersey: Re Delaware \& Atl. Tel. \& Tel. Co., P.U.R. I925D, 60 (r924); Trenton v. Trenton \& M. County Trac. Corp., 92 N.J.L. 6r, ro5 Atl. r36 (19r9); Gately \& Hurley Tel. Co. v. Delaware \& Atl. Tel. Co., I N.J.P.U.R. 5r9.

North Carolina: Re Southern Bell Tel. \& Tel. Co., P.U.R. r92ID, 447.

Utah: Re Mountain States Tel. \& Tel. Co., P.U.R. I922E, 293; Re Utah Power \& Light Co., P.U.R. 1921C, 294.

Washington: Dept. Public Wks. v. Pacific Tel \& Tel. Co., P.U.R. I923D, xr3.

West Virginia: Re Chesapeake \& Potomac Tel. Co., P.U.R. r92rB, 97 (r920).

r8a Supra, note 18. 
various cities according to telephonic populations, and ordered a valuation of the property within, and apportionable to, services within the city of Detroit separately from that of the company's property throughout the remainder of the state. The company had purchased certain independently operated plants at prices which the commission did not approve, and which the commission thought were not capable of profitable operation. A plan was disapproved which would have allowed the charging of rates in Detroit sufficient to make up for losses on these up-state properties, the commission saying:

.... The real question is whether the exchange subscriber in any telephone exchange may be compelled to pay more than a fair return upon the fair value of the property used and useful in that exchange; whether the subscriber in the nonprofitable exchanges of the company is entitled to continuous telephone service at less than the cost of rendering it, such deficit to be made up by increasing the rates in other more profitable exchanges; whether through the instrumentality of public regulation and judicial decree, one person's property may be taken without compensation to him for the use and benefit of others.

.... If the property is not able to sustain itself, then it ought to be discontinued. The company has no right to acquire enormous liabilities and saddle them upon the general public, to be carried by its subscribers in territory where such subscribers are already paying sufficient to constitute a fair return upon its investment. ${ }^{x}$

29 P.U.R. I922E, 584, 585-587. Potter, Commissioner. The reasoning advanced by the commission in this case has had expression in other court and commission opinions. Whether an individual or the inhabitants of an individual city possess a constitutional right not to be charged rates higher than sufficient to yield a fair return on the property used and useful in rendering local service has been held in the affirmative by an Indiana commission and the Indiana Supreme Court, but never decided by the United States Supreme Court. See Re Lebanon Tel. Co., (Ind. P.S.C.) P.U.R. 1925B, II4, I3I; Southern Indiana Ry. Co. v. Railroad Commission, 172 Ind. II3, 87 N.E. 966, 97I (I909). The Supreme Court has held that a complaining shipper must apply to the Insterstate Commerce Commission before resorting to the courts, without deciding that shippers have a constitutional right to be charged only cost rates. In Texas \& Pac. Ry. Co. v. Abilene Cotton Oil Co., 204 U.S. 426, 440, 27 Sup. Ct. 35\%, 355, 5I L. Ed. 553, 559 (1907), the Court said, per Mr. Justice White:

"For if, without previous action by the Commission, power might be exerted by courts and juries generally to determine the reasonableness of an established rate, it would follow that unless all courts reached an identical conclusion a uniform standard of rates in the future would be impossible...." The same reasoning was applied by the Minnesota Supreme Court in St. Paul Book \& Stationery Co. v. Gas Co., I30 Minn. 71, I53 N.W. 262 (1915) in holding that reasonableness of rates fixed by city ordinance could not be raised in a court by an individual user. Other cases in which the point has received consideration are: McCollum v. Southern Bell Tel. \& Tel. Co., I6 3 Tenn. 277, 43 S.W. (2d) 390 (I93I); Brooklyn Union Gas Co. v. New York, 50 Misc. 450, 100 N.Y.S. 570 (rgo6); a master's opinion in Georgia Ry. \& Power Co. v. Railroad Commission, No. I8I, Sept. 25, I924, P.U.R. I925A, 546, not reported in Federal Reports. Compare the language of Mr. Justice Miller in a concurring opinion in Chicago, M. \& St. P. Ry. Co. v. Minnesota, I34 U.S. 4r8, 459, ro Sup. Ct. 702, 53 L. Ed. 970 (189o) with Mr. Chief Justice Taft's opinion in Dayton-Goose Creek Ry. Co. v. United States, 263 U.S. 456, 44 Sup. Ct. I69, $68 \mathrm{~L}$. Ed. 388 ( $\mathrm{x} 924)$. The right where recognized at all is probably statutory only, with the 
Although the Colorado commission had previously approved the use of the company-wide method, it doubted that an application of that method could be carried to the point where a particular city pays rates producing a return "in excess of the operating expense, a fair return and depreciation requirement for that exchange based upon the total investment in such exchange." The commission said that "there must be a limit to which the regulatory body can lawfully go in that regard."20 The commission did not, however, define a limit to the amount of return which could be properly earned in any one exchange.

In Bogart v. Wisconsin Telephone Company ${ }^{2 \mathrm{x}}$ the complainant subscriber argued that rates for Milwaukee subscribers should be no higher than those charged for similar service in other cities in Wisconsin; that rates for local exchange service should be uniform throughout the state and within any particular city for all classes of local service. The company argued that rates for the Milwaukee exchange should be fixed in relation to the statewide revenue needs of the company in that profits in "fat" territory should be permitted to cover losses in "lean" territory. The commission denied both of these contentions. In response to complainant's argument the regulatory body pointed out that due to the necessities of underground conduit and cable construction, larger buildings and more expensive central office equipment plus the greater operating costs of trunking a large proportion of the calls, a uniform rate for local service could not be justified as related to the cost of the service. As related to the value of the service the commission agreed with the view often expressed by other commis-

possible exception of Oklahoma where the state constitution empowers the Oklahoma Supreme Court to act legislatively in fixing rates and that court has consciously so acted in a few instances. See United States Light \& H. Corp. v. Niagara Falls Gas \& Elec. Co., 47 F. (2d) ${ }_{5}^{6} 7$, 570 (C.C.A. $2 \mathrm{~d}$ I93I) reversing 23 F. (2d) 7 I9 ( I928) in which Circuit Judge Manton proceeded upon the theory that the right of an individual consumer to be charged a non-exorbitant rate is a purely statutory right which cannot become vested "unless it is something more than a mere expectation as may be based upon an anticipated continuation of the present general laws." But see Pioneer Tel. \& Tel. Co. v. State, 64 Okla. 304, I67 Pac. 995, 996 ( 19 I 7); Pioneer Tel. \& Tel. Co. v. Westenhaver, 29 Okla. 429, Ir8 Pac. 354, 355 (IgII); Atchison, T. \& S.F. Ry. Co. v. State, 23 Okla. 510, 521, ror Pac. 262, 266 (rgog); McAlester Gas \& Coke Co. v. Corp. Comm., Io2 Okla. I 18,227 Pac. 83 (1924). If it could be demonstrated that prior to the passage of the various regulatory statutes there had existed a common law right in the individual consumer or city to pay no more than the cost rate for local service, then the proposition might be advanced that this right remains in those states where the regulatory statute has not definitely repealed it, as was suggested in the concurring opinion of Circuit Judge Stone in Homestead Co. of Des Moines v. Des Moines Elec. Co., 248 Fed. 439, 45I (C.C.A. 8th, I9I8). Reasoning such as this, however, is too conjectural to be constructive. See Kline, Origin of the Rule Against Unjust Discrimination, 66 Univ. Pa. L. Rev. I23 (I918).

${ }^{20}$ Re Mountain States Tel. \& Tel. Co., P.U.R. I920C, 549.

${ }^{25}$ P.U.R. 1916C, 1020, 1089. 
sions that the greater the number of possible connections available to a particular subscriber without the payment of a toll charge, the greater the value of service in the large city exchanges. In answering the company's contention the commission said that the Milwaukee exchange constituted "practically a separate entity," and that if rates therein were to be fixed with reference solely to the financial needs of the company as a whole it might be led into concluding "that rates in Milwaukee could not be adjusted merely because the company had chosen to develop unprofitable business in other parts of the state.".

The reorganized Wisconsin Public Service Commission has recently, however, approved the company-wide method. ${ }^{22}$ How far the new commission will go in applying the method waits to be seen. Under the Wisconsin statute the commission is empowered to use either method in particular cases. ${ }^{23}$

In Re Indiana Bell Telephone Company ${ }^{24}$ the Indiana Public Service Commission quite definitely settled the question as to how far the company-wide method will be carried in that state. In adopting the method and in grouping the communities served by the company into categories, the commission said that it had no intention of fixing rates in one city or group of cities which would make up losses from lower rates in other cities and communities, or of requiring the company to operate any one exchange at a loss. Certain of the exchanges operated by the company were unprofitable, and it was argued that losses there incurred must necessarily be shifted to the more profitable exchanges by the imposition of rates in the latter group higher than necessary to provide a fair return on the property used in such latter group. The commission said that if the rates authorized for the poorer exchanges did not permit a profit it did not intend to consider that fact in computing the return as a whole for the entire statewide property. ${ }^{25}$

The Indiana statute provides for hearings and commission investigation into the reasonableness of local rates upon a petition from a specified number of residents or business firms. ${ }^{26}$ Similar provisions are to be found

${ }^{2} \mathrm{Re}$ Wisconsin Tel. Co., P.U.R. r93 IE, r35, I40-r4r.

${ }^{23}$ Wis. Stat. (I929), $\S \mathrm{I} 96.03$ (2): "For rate-making purposes the commission may consider two or more municipalities as a regional unit where the same public utility serves said municipalities, if in its opinion the public interest so requires."

${ }_{24}$ P.U.R. I924A, I.

${ }_{25}$ P.U.R. I924A, I, 37: "The rates requested by the company for these small exchanges included in Group ' $\mathrm{T}$ ' should be authorized and the deficit below a reasonable return not considered in the computation of the rate of return for the property as a whole."

${ }^{26}$ Ind. Burn's Ann. Stat. (1926), \$\$ I2728, 12680; Ind. Acts 1913, p. 167. 
in other public utility enactments. ${ }^{27}$ The Indiana act contains no specific requirements as to methods of determining the reasonableness of local service rates. Nevertheless it has recently been declared that the statute prescribes the municipality as the proper unit upon which rates should be based. In Wabash Valley Electric Company v. Singleton ${ }^{28}$ the regulatory body had ordered the company to reduce its rates for electric service in the city of Martinsville, Indiana. The company carried the order to a federal court, on grounds appearing in the following excerpt from the court's opinion:

.... It is the contention of plaintiff that its electric property and system, as a whole, should be the unit, and that the schedule of rates and charges for Martinsville should be tested by their effect upon its entire net revenue and the relation of such net revenue to the value of its entire used and useful electric property. The defendants contend that the city of Martinsville should be considered as a segregated unit for the purpose of determining its schedule of rates.

The court referred to the Indiana statute and interpreted it as requiring each municipality to be considered as a unit in the fixing of rates, saying:

Whether any division of the state, other than a municipality, shall be designated as a unit for the purpose of fixing rates for a utility, is a matter of public policy to be exercised by the Legislature. Until that is done, neither the Public Service Commission, nor a court, can consider any other unit than that which is now fixed by the Legislature, namely, the municipality, in establishing a schedule of rates for the services of a utility in such municipality. 29

The litigation was carried to the United States Supreme Court, and affirmed in Wabash Valley Electric Company v. Young. ${ }^{30}$ The Court, through Mr. Justice Sutherland, said:

Whether the method afforded by the state statute thus construed is in accordance with sound policy is a question with which we are not concerned. See Wabash, etc., Railway Co. v. Illinois, I 8 U.S. 557, 577, 7 S. Ct. 4, 30 L. Ed. 244; The Minnesota Rate Case, 230 U.S. 352,4 I6, 33 S. Ct. 729, 57 L. Ed. I5Ir, 48 L.R.A. (N.S.) II5I, Ann. Cas. 19r6A, I8.

In addition to what already has been said, it should be noted that appellant not only furnishes electric current to the fifty separate and unrelated towns and cities, in none of which the plant is used or useful for the rendition of service to any other town or city, but appellant also carries over its lines and delivers to others of the affiliated

${ }^{27}$ Ala. Code Ann. (r928), § 9773; Ariz. Rev. Code (r928), § 714; Cal. Gen. Laws (r923), Act 6386, §60; Colo. Comp. Laws (I921), § 2954; Conn. Gen. Stat. (Revision I918), c. I91, $\S 3635$, Public Acts r920-r921, c. 328; Mont. Rev. Code (r92r), $\$ 3897$; Ore. Ann. Code (1930), $\S 6 \mathrm{I}-24 \mathrm{I}$.

${ }^{28}$ I F. Supp. 106, 108 (Ind. 1932). Baltzell, J.

${ }_{29}$ Ibid., xog. And see also Indiana General Service Co. v. McCardle, I F. Supp. II3 (Ind. I932), accord.

${ }^{30} 287$ U.S. $488,489,49$ I, 53 Sup. Ct. 234, 235, 237 (Jan. 9, I933). 
companies, as intercorporate transactions, varying portions of the entire current borne by its lines for subsequent distribution by the affiliated companies to their customers, including many towns and cities within their respective territories. This intermingling of the business and distributing activities of the several companies results in such elements of uncertainty in respect of the proper evaluation of appellant's participation therein that, standing alone, it would go far in the direction of justifying the rejection of the contention that the due process clause requires that appellant's entire distributing system should be included in the basic unit. In the light of all the facts and circumstances, we hold that an adjustment of rates for the municipality here served by appellant in accordance with the method adopted below is consonant with state law and immune from constitutional attack.

It should be noted that there exists a difference between telephone and electric service insofar as use of the equipment is concerned. While in the above case it may have been approximately ${ }^{3 \mathrm{x}}$ accurate to say that in none of the fifty towns and cities served was the local plant used or useful in furnishing electric current to any other town or city, such is not the case where telephone service is concerned. The completion of toll or long distance calls requires the use of the local telephone plant in each city, and a wide extension of telephone service is then desirable. There may be an incommensurable value or advantage to telephone subscribers generally to have available a widespread system. Whether that value or advantage can or ought to be reflected in the rates charged is a matter upon which there is room for difference of opinion. It is to be noted also that the long distance service is a separate service in the sense that a separate schedule of rates is applied to it, and also because additional and more expensive equipment and apparatus is necessary for that service, as well as greater operating costs. Perhaps the value or advantage referred to ought to be paid for by those who use the long distance service.

It is interesting to observe that while the Court's reference to "elements of uncertainty" in evaluating the company's participation in the intercorporate transactions mentioned was here used to justify a rejection of the company-wide thesis, very similar elements of uncertainty were used in the commission opinions quoted to justify adoption of the companywide method.

The lower court's interpretation of the Indiana statute should not be regarded as prohibiting the use of the company-wide method, as the language might seem to indicate. The case merely holds that a particular city may raise the issue of reasonableness of local rates under the terms of the statute, and that an electric company has no constitutional right to insist upon a system-wide valuation whenever such issue is raised. The

${ }^{3 x}$ Although certain city plants may not be used in furnishing service to other cities, such plants may be useful for standby service. 
lower court went too far when it construed the statute as prescribing the municipality as the basic appraisal unit and prohibiting the commission and the court from considering any other unit. This last is dictuin merely, and not at all necessary to the decision. The court's reasoning assumes that the commission's use of the company-wide method is tantamount to denying to municipalities subsequent evaluations of the property locally used and useful, a conclusion quite obviously non sequitur. The Indiana commission quite recently fixed electric rates on the system-wide basis, finding it only necessary to remark that "the right of individual communities to complain against discriminatory rates would be preserved." ${ }_{32}$ The lower court's language also assumes that the validity of local rates can be tested in no other way than by relating the revenue therefrom to a local segregation and apportionment of property values and operation expense. Another way to check the reasonableness of local rates is the simple one of comparing them with the rates charged in other communities of approximately the same size and operating conditions. In the last analysis segregations and apportionments, though based on an accurate inventory, are necessarily matters of estimate. Mathematical accuracy is no more possible therein than it is in a well informed and judicious spreading of the revenue burden over various groups of cities classified according to population and installation and operation expense.

Under the Missouri statute ${ }^{33}$ a municipality has the right to a hearing on the reasonableness of local rates, as in Indiana. The Missouri commission, perhaps influenced by the federal court's decision in the Martinsville Case, concluded that apportionments of the total property valuation should be made among the various municipalities served by a company rendering water, gas, electric, ice and interurban transportation service, saying:

.... it occurs to us that we could not well avoid apportioning the value of the unified property among the communities served even if the positive provision of the law did not so require. The reason is that the entire revenue of the company is derived from rates received from the municipalities and districts as separate units, each paying for the service rendered under separately filed, independent schedules. This practice must, in general, be continued. ${ }^{4}$

But query, if schedules be filed to apply to particular groups of cities?

The Idaho statute ${ }^{35}$ prohibits preferences to be maintained between

${ }^{32}$ Re Public Service Co., P.U.R. 1932B, I86. In Bloomington v. Public Service Co., P.U.R. 1932A, I77 and in Logansport v. Northern Indiana Public Service Co., P.U.R. I932D, ro the Indiana Commission used the local-area method in fixing local rates.

33 Mo. Rev. Stat. (1929), $\$ 5202$.

${ }^{34}$ Public Service Comm. v. Missouri Utilities Co., P.U.R. I932E, 449, 49r. By the Commission.

35 Idaho Ann. Code (1932), § 59-315. 
localities and between classes of service, a provision common to many of the various state regulatory statutes. Under this statute an electric company was authorized to increase rates in one city to a point where the advantage over other cities served by the same company was eliminated..$^{36}$

Under a similar statute in $\mathrm{Utah}^{37}$ a city sought to have set aside a commission order which increased local exchange telephone rates. The argument before the Utah court was not based on proof that the increased rates were higher than those charged for similar service in other municipalities of comparable size and operating conditions, but upon the contention that the statute necessarily prohibited the company from charging such rates as would yield a greater return in one city than was earned in other communities. The court found, however, that the rate of return was less than the company was probably entitled to and held the increase justified, saying:

.... It is well settled that each rate should be compensatory, and that a utility cannot be required to perform service at a rate which is confiscatory. . . . It is also recognized that it is impossible to construct a rate structure so that the rate of return will be uniform on all rates, and that neither the utility nor the customer has the right to insist upon uniformity of the rate of return. . . . It was wholly unnecessary that the commission make any finding as to whether or not other exchanges in the state would yield a lower rate of return. A comparison of other rates would be persuasive or controlling only where shown that conditions were comparable and that the rates used for comparison were just and reasonable rates..$^{38}$

In Re Northwestern Bell Telephone Company, ${ }^{39}$ decided by the Minnesota Supreme Court, the city of Duluth was resisting an order of the Railroad and Warehouse Commission which increased local exchange telephone rates in that city. The municipality based its opposition partly on the contention that the commission's order was ineffective in that it was not made as part of a state-wide adjustment of the telephone company's rates, and partly on the contention that the rates established by the order were discriminatory against Duluth in favor of other cities in the state. The company argued that the Minnesota statute ${ }^{40}$ did not pro-

${ }^{36}$ Re Idaho Power Co., P.U.R. 192IC, 238. See also Re Idaho Power Co., P.U.R. 1924C, 313; Re Public Utilities Consol. Corp., P.U.R. I932A, ro9; Re Blackfoot Water Works, P.U.R. Igr8E, 463 .

37 Utah Comp. Laws (I9I7), § 4789.

${ }^{38}$ Logan City v. Public Utilities Comm., 77 Utah 442, 296 Pac. I006, I009 (I93I). Folland, J. To the same effect is a master's report printed in full in State ex rel. Hopkins v. Southwestern Bell Co., II 5 Kan. 236, 223 Pac. 771, 790 (r924).

${ }^{39}$ I64 Minn. 279, 204 N.W. 873 (1925).

$4^{\circ 0}$ Minn. Gen. Stat. (1923), § 5304; Laws I915, c. 152, § I8. Minn. Mason's Stats. (1927), $\S 5304$ : "The requirement as to reasonableness of rates shall apply to each exchange unit as well as to telephone plants as a whole." 
hibit discrimination between communities; that the rates as established were not discriminatory against Duluth because applicable only to a local service within the Duluth exchange area and limited to and obtainable only within that area; that it was not discriminatory for a company to earn a higher return in one city than was earned in other cities and that the local-area method was a proper method of fixing local exchange rates. The court declared that the city's contention, that exchange rates should be adjusted only as part of a state-wide adjustment, was an "untenable" theory, and found that the higher Duluth rates were justified because of higher installation and operation costs than were incurred for other cities of comparable size.

\section{PUBLIC POLICY AND THE CHOICE OF A RATE-MAKING UNIT}

Under the amended Wisconsin statute ${ }^{4 x}$ the Public Service Commission is empowered to treat two or more municipalities as a regional unit whenever in its opinion the public interest so requires and the cities are served by the same utility company. The statute does not define what is meant by "public interest." The question arises at once whether public interest means that which the Georgia, Oregon, New York and Pennsylvania commissions had in mind in the opinions herein referred to. ${ }^{42}$ It will be recalled that these commissions advanced the proposition that telephone service increases in value to the individual subscriber as the service is extended throughout an entire state, and therefore the larger and more prosperous cities should be required to pay such rates as would permit the rendition of service to communities not of themselves able to sustain the operation costs therein incurred.

It may be possible to distribute the price burden so that utility service can be rendered in every small hamlet in the United States. It is not denied that such a development would be of an advantageous social significance. It is likely, however, that public opinion would soon insist upon a more practical definition of public interest.

If, as asserted by the Colorado commission ${ }^{43}$ certain areas and communities are tributary in a commercial and industrial sense to a central and larger city, and communication with the marketing area is essential in the interest of the producing and distributing center, an instance is pre-

${ }_{41}$ Quoted in note 23 , ante.

$4^{2}$ See pages $453-55$, ante. -

${ }^{43} 3$ Colo. P.U.C. supra, note I8, quoted in Public Service Comm. v. Mountain States Tel. \& Tel. Co., (Colo.) P.U.R. I924C, 545, 557-558. The theory on which the commission had approved the company-wide method is that Denver should be made to pay a higher percentage of the intrastate return than other towns of the state because such other towns are commercial tributaries of Denver. 
sented in which public interest may require not only an application of the company-wide method of evaluation but also one in which a greater rate burden may be imposed upon the subscribers in the central city than is proportionately equal to that imposed upon the tributary communities.

Where an application of the local-area method would so increase the expense of rate making that the consequent tax and rate burden upon the cities involved would more than counterbalance slight inequalities in rates and charges possible under the company-wide method, the public interest would be recognized by a choice of the latter method, of course. Whenever any method cuts down the expense of rate proceedings and accomplishes a fair valuation of property as well, that method should be approved. On this count the company-wide method unquestionably has the advantage, as nearly all the commissions have admitted. It seems only sensible to permit commissions to determine this question for each particular case.

Where large electric, gas or water companies serve a number of communities from central manufacturing plants which distribute the product over the entire area served, there would seem to be useless repetition in segregating and apportioning values and expenses as many times as there are cities involved. For the very large companies the process of valuing one piece at a time could only result in inequalities between the various cities for the reason that property and equipment values and operating expenses will fluctuate over a period of time. When the last city had been granted a local valuation of the company's property therein used and useful, on pricing units then regarded as fair and reflecting the present market on materials and labor, city number one in the list would require another investigation.

Where each municipal area contains a complete operation unit, both a central manufacturing plant and a distributing system, the above criticism would not be quite so applicable. Delay in valuing the last city would not bring into being rate discriminations on service rendered in large part from the same plant and equipment. In such situations, even though executive and accounting work is performed elsewhere, public interest would not require a company-wide rate case. Local valuations can be made whenever a municipality becomes dissatisfied with local rates. The Wisconsin statute permits the commission a choice in the matter. The Michigan statute ${ }^{44}$ may hinder a choice.

${ }_{44}$ Mich. Comp. Laws (r929), § I Io99: "Upon complaint in writing by any consumer or city, village, or township . . . . relative to the price of the electricity sold and delivered in such municipality, ... the commission shall investigate . . . " and fix the rate by considering all elements which enter into the problem; "provided further, Where identical or substantially 
The various regulatory enactments fall into two main divisions. First are those statutes which merely provide for hearings before the commission upon the complaint of a municipality or a specified number of resident persons, firms or corporations. The Martinsville Case, ${ }^{34}$ though far fetched in reasoning, is a definite interpretation of this type of statute. The Odell Case ${ }^{45}$ does not cite or refer to the Michigan statutes ${ }^{46}$ in denying the separable contention of the city of Detroit that the reasonableness of local telephone rates should have been based upon a local segregation and apportionment. That court seems to have depended upon the master's report not only for the facts but also for the law of the case.

The second type of statutory enactment discussed herein forbids the granting or maintaining of undue preferences or advantages between localities and between classes of service. If the federal court in the Martinsville Case was seeking statutory authority for its dictum that no other unit than the local area could be treated as the basic unit for rate making purposes, it is strange that no reference was made to the Indiana preference provision. ${ }^{47}$ It would seem perhaps that this provision would lend more support to the dictum than the statute actually cited. Aside from conjectures of this sort, however, the Utah $\mathrm{Case}^{38}$ may be regarded as construing provisions of the second type as requiring only that there be no differences in charge not based on differences in service rendered under comparable conditions in other localities. But the Utah Case is no authority for the proposition that only local valuations can prove the existence of unjust discrimination between localities or communities. The decision does not preclude the Utah commission from using the company-wide method of rate making in subsequent rate proceedings.

Aside from the indefiniteness of the Minnesota statute as construed by the Supreme Court of that state, the court's decision possesses the advan-

identical rates prevail or are established, or shall hereafter be established in two [2] or more contiguous municipalities or communities served . . . by the same person, firm or corporation, the territory so served and to be served shall be treated as a unit for the purpose of fixing rates and no such rate or rates shall be changed with respect to one [I] or more of such municipalities or communities so as to establish any difference of rate within the territory so served, unless and until it shall be shown that the continuance of such identical or substantially identical rate or rates will work substantial hardship to some municipality or person, firm or corporation affected thereby."

${ }_{45}$ See note 4 , ante where the case is cited and a portion of the court's opinion quoted.

${ }^{6} \mathrm{Mich}$. Comp. Laws (I929), $\$$ II704, Ir 7 ro.

47 Rev. Stat. Ann. (Burn's rgr4), $\S$ I0052k4: "If any public utility make or give any undue or unreasonable preference or advantage to any particular person, firm or corporation, or shall subject any particular person, firm or corporation to any undue or unreasonable ...." etc., it shall be guilty of unjust discrimination and fined. 
tage of leaving the Minnesota Railroad and Warehouse Commission free to choose between methods of rate making in specific instances.

It is suggested that in those states where any doubt may exist as to the power of the regulatory body to choose between methods of rate making, the Wisconsin statute can be copied with good effect. Administrative discretion should be left free to apply any method which best suits the convenience of the particular case and promises substantial justice to the parties concerned. Freedom of choice under precautionary provisions for appellate review, may permit continued progress in the development of rate making methods, and be perhaps the best public policy in the long run.

\title{
SOME DISTINCTIVE FEATURES OF A LEGAL AID CLINIC COURSE
}

\author{
JoHN S. BradwaY*
}

$\mathbf{I}^{\mathrm{N}}$ NSTRUCTING students by means of a legal clinic is a comparatively new departure. This educational device, which has already found favor in other fields of training-for the physical sciences through laboratory work; for the social sciences through field work; for the medical field through highly organized hospital clinics, and for religious education through special assignments - is making its way slowly into the domain of law. It contrasts with earlier approaches to the task-the apprenticeship system, instruction by lecture and textbook and the case method. The clinical approach differs from each of these in objectives, in method of instruction, and in material or content. It deals with a mental process as common to the lawyer as the judicial process is common to the judge. It throws into relief a new responsibility of the law school toward the community. These three phases of the problem-the differences from other methods of education, the nature of the process of thinking common to all lawyers and the added responsibility of law schools to the community - are the subjects of this paper.

THE CLINIC METHOD OF INSTRUCTION AND THE OTHER MIETHODS

A. The Objectives of the Clinic Course.-The clinical method of instruction in law is designed to accomplish five primary objectives. First, like the apprenticeship system, it gives the student a practical course in

* Director, Legal Aid Clinic, Duke University.

I A fairly complete bibliography of the material on the subject of legal aid clinics will be found in 30 Mich. L. Rev. go5 (1932). 
practice as contrasted with a theoretical course. It adds experience with "law in action" to that already gained from "law in books." It bridges the gap between the theory of law school and the practice of the profession. ${ }^{2}$ But from this point on, modern clinical instruction in law schools has novel features.

Second, it acts somewhat as a forum where the student may synthesize his theoretical experience gained in the different courses, substantive as well as procedural, that he has taken. In them, the tools are forged; in it, one finds out how to apply one or more tools in the solution of actual unsolved human problems. Misuse or lack of control will result inevitably in serious detriment to the client and a consequent economic loss or lowering of the lawyer's prestige, so the element of public responsibility is present. The average law school curriculum cuts the seamless web of the law arbitrarily into segments, such as Contracts, Torts, Future Interests. A single clinic case may have ramifications in many fields of substantive law, as well as in the domain of practice. ${ }^{3}$ The rules of law must be blended, harmonized, and evaluated with respect to the living case. Consequently, the work is in no sense a review of other courses. Rather, it is a voyage of discovery. Sometimes materials in other courses are used. Often the student must deal with a field in which he has had no previous classroom instruction. In such work the seamless web quality of the law is brought forcibly to mind. Resourcefulness is at a premium. The benefits of study in the other courses are seen to be in the development of analytical powers, not merely in learning specific rules. The legal aid clinic student of necessity explores all legal avenues which promise even remotely a means of reaching the desired goal. He dare not risk his client's rights on any narrower survey. Hence, he comes in time to feel at home in the general field of law as he previously did in the more restricted limits of each one of the courses he had taken.

Third, viewing the law as one of the social sciences, the clinic student has the opportunity to study the client as a whole in relation to the community as a whole. This introduces a distinctly new element-the human equation. Not only the legal problems of the client but all his problemssocial, economic and otherwise - should pass in review. Before advising

2 There is a substantial amount of literature attacking legal education for failure to bridge adequately this gap. For example, Alfred Z. Reed, The Missing Element in Legal Education (x929); Jerome Frank, What Constitutes a Good Legal Education? xg A.B.A. Jour. 723 (1933).

3 The variety of problems arising in legal aid clinic from the case of a single individual is a most interesting field for study. As examples, see the following cases in the Duke Legal Aid Clinic: Nos. 69, 54r, 5or. 
or acting, the student must have as complete a picture as possible of the human being with whom he is dealing. Only with this is he prepared to decide what he is to do with the case. The ultimate goal, and the means of reaching it, may be achieved by the use of resources in the field of law or in the field of some other professional activity, such as medicine, social work, or religion, or by a combination of several of the social or physical sciences. Hence, the approach to the material is unlike that in other law school courses. The client is not always to be satisfied by the statement, however accurate, that such and such is the law. Often that is merely the point of departure. He insists on being told what to do. Hence clinical training takes AB, XY, Greenacre, My Old Horse Susan and other symbols which have done yeoman service in hypothetical cases and clothes them with fiesh and blood and other objective reality. The dissatisfied client who pays for "A" grade work and receives legal services valued at "C -" may report the situation to a grievance committee or broadcast his lawyer's inefficiency to the four winds. ${ }^{4}$ Preparedness to meet such situations comes from grim experience with actual clients.

Fourth, the clinic student faces the problems of legal etiquette as contrasted with legal ethics. He learns to distinguish those swift unwritten techniques which are characteristic of the best practitioners and are not found in the armory of the less effective members of the bar.

Finally, the clinic course introduces the student to the case at the beginning rather than at the end. It forces him to think constructively and to plan a campaign..$^{5}$ The process is quite different from asking him to analyze a completed case embalmed on a printed page. By analogy, a medical school would hardly allow one of its students to treat a living patient unless the embryo physician had advanced further in his studies than the dissection of a cadaver. This is no reflection on the importance of such dissection. It is apparent rather that the clinical objectives bring

4 As examples of dissatisfied clients, note the following cases in the Duke Legal Aid Clinic involving complaints against members of the bar: Nos. $1,32,45,75,512,585,592$. The procedure for handling these cases sometimes involves a courtesy letter to the attorney in question. At other times the case is taken up directly with the grievance committee. During the last few years legal aid societies have collected statistics of complaints against lawyers. In r924, fifteen societies reported 976 such cases. In r930, seventeen sacieties reported 1628 . For the procedure employed by legal aid societies generally in handling such claims see, Reports of Committees for $1932-1933$, p. 59, discussed at Convention of National Association of Legal Aid Organizations held in Chicago, Ill., October 5 and 6, 1933 .

${ }^{5}$ For material indicating tentatively the nature and extent of this process see, Bradway, Supplement No. 2 of the Handbook of the Legal Aid Clinic (1933), c. I "Suggestions for Recording the Plan of Campaign."

Definite instruction in this work is given in the clinic course at Duke University. 
within our mental horizon a series of factors which are of significance in the educational field. We compare them with the elements in the other systems by which students have been transformed into lawyers.

B. The Unique Elements in the Clinical Approach.-The clinic course differs from other methods of instruction in approach, in method, and in material or content. It is because of the last four objectives mentioned in the foregoing section that the clinic instruction differs from the apprenticeship of an earlier era of legal education. That period may not now be recaptured, but that is no reason for keeping certain of its benefits beyond the reach of present day law students. Our problem is how to fit a new piece of improved machinery into an existing system which has outgrown apprenticeships.

Comparing the clinical method with instruction by lectures and textbooks, we find a wide divergence. The approach of the textbook method seems to be to place in the mind of the student a body of rules of law, concisely stated. In the clinic course knowledge of the rules of law is only one factor in a great multitude of elements which go to make up a lawyer's mental fibre. Flexibility of mind, resourcefulness, initiative, imagination, discretion and judgment in the use of the power of legal sanctions rather than a knowledge of a set of rules are the characteristics by which we judge students. The methods of instruction differ because in a clinic the student is brought in contact with flesh-and-blood clients, clerks of court, opposing counsel, witnesses and other people-rather than with books or a lecturer. The training results in personality development. Experience in dealing with unexpected situations is emphasized rather than the ability to reach into the musty closets of one's memory and drag out a rule of law. Finally, the materials differ. Again, in one case it is law in books; in the other, law in action.

The distinctions between the clinical method and the case method of instruction are equally important. The approach of the case method includes an effort to develop in the student the power of thinking analytically and to familiarize him with the original material of court decisions rather than the previously digested information in textbooks. ${ }^{6}$ The clinic is designed to teach the student to think constructively as well as analytically - to act creatively as a lawyer in addition to thinking like a judge or legal scholar. The case method is conducted by supervised class discussion under laboratory conditions. In the clinic office the client is a third party, present in person or by proxy. This makes a great difference. As

${ }^{6}$ Among the material on this subject perhaps as objective a study as any is contained in Redlich, The Common Law and the Case Method (I9I4). 
there are no limitations on the situation presented one cannot prepare for it as by reading assignments but must face the door that opens to let in a novel situation. Neither student or instructor can anticipate the details of the initial contact. This presents a new kind of challenge. If the student possesses qualities such as dependability, leadership, calmness under fire, the clinical experience brings them out.

The case method, for its raw material, takes usually a completed decision of the court or a hypothetical set of facts. The clinic starts with a raw human problem, often untouched by the legal mind and one that may never become the subject of court decision. The clinic course is not just another course. It is a new approach.

All this is just another way of saying that the main distinction between the two is that they deal with different aspects of a series of mental processes found in the activities of the legal profession. It is important for us to consider just what mental processes are required in the handling of a case. Otherwise we cannot intelligently provide a student with opportunities to prepare himself for the tests he will be forced to undergo at the hands of the public.

THE MENTAL PROCESS OF THE PRACTICING LAWYER

Justice Cardozo has made familiar the Judicial Process. ${ }^{7}$ This is a mental exercise by which the legally relevant factors in a case are evaluated and a decision reached as to what is, or what should be, the law. The material necessary for its functioning is found to a large extent in the records of cases coming for decision in an appellate court. It is, however, only one part of that more extensive procedure. One asks-where do the records in appellate cases come from, and what sort of mental process is required to produce a condition of orderliness sufficient to warrant a lawyer in submitting a question to judicial determination.

The whole process, extended to the full, contemplates the initial taking up of a human difficulty and its ultimate solution by the resources of the law. The first stage consists in gathering from lay minds, public records, and elsewhere, miscellaneous materials-some legal, some extra-legal. These must be tested for their relative usefulness to the client, translated into the field of legal thought and organized, reduced to form on paper. The lawyer must make a series of decisions regarding them. Does the best solution lie by way of legal resources or should the client go to some other professional group to receive adequate treatment? Is the case capable of solution by conciliation, legislation, education procedures, or only by

7 Cardozo, The Nature of the Judicial Process (r928). 
litigation? Only a small proportion of the matters arising in a law office ever get into court. So the lawyer who knows only the technicalities of pleading is at a disadvantage. Even the ability to draw a complaint, draft a brief or argue a point of law is not enough. The practicing lawyer must be the master of many techniques.

The second stage in the disposition of a human problem involves the judicial process of taking these partially organized materials and refining them still further by a decision. The third stage is that allocated to the legal scholars, who inter alia, by comment and criticism, take the completed results of the lawyers and judicial processes and relate them to a scholarly and scientific system of law or discuss the lack of conformity.

If the foregoing is admitted to be a fair statement of the general legal process, then we see even more clearly the need for a difference in emphasis in training men to be lawyers as contrasted with the needs of those planning to be legal scholars. The practicing lawyer is engaged in the building process. He looks forward from the most scattered, uncoordinated materials. Starting at the beginning of a problem, he faces the kaleidoscopic life about him and must select from it bricks with which to build his case. $\mathrm{He}$ is the prospector digging for precious metals in the desert or lonely mountains. By the time the case gets to the legal scholar by way of the advance sheets, it has passed through two series of legal minds. Disorder, extraneous circumstances, among other factors, have been eliminated, until only the purely legal aspects of the controversy appear on paper. Here the scholar critic may take the refined metal and mould it into a thing of beauty. The artist sits down before a blank canvas or block of marble and creates. The critic evaluates the completed task according to recognized standards. While the same standards may be common to both, the approach is different. Hence training of the law student that does not visualize the creative approach ignores much that he will need most in his daily life. The tendency to regard such training as nothing more than a learning of certain trade routines may have had something to do with the disinclination of some lawyers to raise the level of their work to the field of art. ${ }^{8}$ Certainly in current legal education there is a place for emphasis on the training of the lawyer as such, so that when practicing law in the grand manner he may not in any case fail the court, the client, his profession or the community. If lawyers generally were taught to adhere to increasingly high standards of practice in all its

${ }^{8}$ In case No. 289 the Duke Legal Aid Clinic was called upon to help a mature lawyer untangle a snarl into which he had dragged himself by failure to read the rules relating to the taking of an appeal. The clinic staff, of course, could only surmise what the client thought of the way the case had been handled. 
phases, the materials out of which scholars build a legal system would become better in quality.

But the technical ability and a sense of ethical propriety, however highly developed, do not round out the stereotype lawyer who is the ideal leader. Of the other factors one of the most important is social vision. One need hardly repeat that lawyers are essential in building social programs of the future. To be able to make their contributions it is necessary that they be given a viewpoint which senses responsibility to the community.

Some men are moved by the printed word; others by personal contact with their fellows. It would be unfortunate for the leadership of the Bar and its public prestige if a wide range of opportunities were not afforded men to kindle their interest. Certainly there are law students to whom the plight of an individual client is a greater incentive to activity than any book, lecture, or classroom discussion. ${ }^{9}$ For these men an interpretation of the part which a lawyer may play in the broad field of public welfare, by the example of a carefully handled interview, a well tried case, a conciliation procedure, a bit of legislation, may be inspirational.

Human problems are innumerable. Of them, great quantities are solved in the fields of medicine or the social sciences and elsewhere. The outlook on life available to the legal profession is, at best, but a segment of the whole. But there is reason to urge the broadest possible understanding of community problems and a cooperative endeavor with the other professions in meeting them. The public is coming more and more to require it.

The law student who plans to practice law needs for his own sake to be aided in securing this broad viewpoint. The collective value to the profession and the public of a constantly increasing group of men with a desire toward this sort of intellectual leadership would be very great. We come to consider then the obligation of the law school to provide such educational opportunities.

\section{RESPONSIBILITY OF THE LAW SCHOOL TOWARD COMMUNITY AND INDIVIDUAL CLIENT}

The legal aid clinic augments and extends the educational opportunities offered by the other courses. It directs the attention of the student to

\footnotetext{
9 In case No. 6ri of the Duke Legal Aid Clinic the student awoke to the plight of a man charged with forgery. After securing his acquittal in a hotly contested case, the student brought to bear upon the client the resources of the School of Religion and the School of Medicine providing an excellent example of inter-professional cooperation in the solution of a specific human being's problems. See also, A Problem for Coordinated Medical and Legal Talent, Wiley D. Forbus and John S. Bradway, 26 Southern Medical Jour., No. 9 (I933).
} 
the first part of the "legal process," just as the case method emphasizes the second, the law review work the third. It develops a viewpoint. Recognizing that law students who have this training are better prepared for certain tasks, we may inquire whether there is any obligation on the law school to train them. One may say that it is the duty of a law school to teach only law. Another may contend in favor of the exclusive importance of the analytical approach. Still another stresses the functional approach. Is there room for or value in a new technique based on factors which the clinic class may regard as important? The answer may be approàched from various angles. For our purposes the student himself is the main consideration. What does law school do for him as an individual? How does it prepare him to meet his future employers and clients on their own ground? As to that we may not generalize.

The practical problem faced by the student is one of adjustment to a new environment. While the situations may vary infinitely with the individual, it is possible to make certain specific classifications. One group of law graduates is headed for a business career, with legal training as a background. With them we have no particular concern because they pass out of the legal field. Of those who remain, by far the largest portion become practicing lawyers. After some years, a few of them may become judges. Only a handful go into the field of law teaching.

The faculty and the student both have some concern as to his fitness for his chosen work. While we have devices to check a man's analytical ability, his other characteristics have not as yet been brought within the province of orderly testing. Hence the existing process of legal education, unlike medicine, turns its men out without a guide in certain vital directions. A sense of devotion to the ideals of scholarship in a law student is an inadequate point of view with which to face situations with which legal scholarship has no concern. The consequences to the community and the individual of such oversight may be very grave.

The situation is comparable in some respects to the operation of a factory which, concentrating on the production of some particular article, allows valuable by-products to go to waste. Somewhere along the line the law student will face a client who is dissatisfied with the work done. When it comes to fixing responsibility for the mistake, there are three possible culprits - the student, the law school, the bar. The student frequently is the innocent victim of a system of education which prepares him for only one part of his task. The modern bar is not equipped, nor has it the time, to do thorough educational work supplementing the law school's task. In the last analysis the primary obligation to provide a well rounded program-no matter how much it costs or how difficult of ad- 
ministration-rests on the law school. The public, which is the final judge of values over a period of time, will be satisfied with nothing but the best product. In facing its share of this obligation to the public, the law school may take various extreme positions. It may insist that it has nothing but a limited responsibility or that from practical considerations it is doing the best it can. On the other hand, it may make reasonable efforts to explore these broader fields for the purpose of determining how effectively such training can be given.

Those law schools which have experimented with the clinic system even in small degree seem to be adopting the following attitude. For them a well rounded student as a prospective leader is to be preferred to the specialist. In spite of the fact that members of their faculties are admittedly specializing, they appreciate that a broad basis of preparation is likely to produce a more effective lawyer. Specialization may begin so early in a man's work as to dwarf his outlook. The student who has been introduced to a number of the situations with which he will have to deal, and who has received some instruction as to recognized ways and means of handling himself, seems more likely to turn out a leader whether or not he subsequently specializes.

In a situation where each critic measures the value of law school training from the background of his own experience, one can hardly outline dogmatically a perfect system. But one may study the failures which result from neglect of certain factors in legal education. The student suffers if he does not have clinical training. It is customary to judge the success of the educational process by its outstanding leaders. May it not be equally sound to base our study on the failures. The blame should be laid where it belongs.

Many men will never make well rounded lawyers. ${ }^{\mathrm{To}}$ As a result of train-

${ }^{x}$ The Iegal Aid Clinic student is more than a name or a location in the classroom. An adequate study of the man and his abilities would include a social case history and a complete psychiatric examination. In a sense the clinic experience is a very broad scale aptitude test. But it is aptitude for general practice rather than as a law student. Perhaps this study should parallel the student's work for three years instead of being limited to third year men. The work coming to a clinic organization is classifiable into the simplest sorts of work-studying the geography of the courthouse, securing information from public records, serving papers, which might be done profitably by first year men. In the second year certain briefing problems might be assigned. The interviewing of clients, preparation of plans of campaign and preparation for trial of cases would be reserved for the final year. Such a process would disclose strengths and weaknesses in time for both student and instructor to handle them.

In a sense the clinic work is a study of individual mistakes. They cover a wide range. Eventually they may be tabulated, studied, and preventive measures devised to anticipate them. Among the simpler errors are the following:

In case No. 6ro of the Duke Legal Aid Clinic the student was requested by counsel for the defendant to brief a point of law and assist at the trial. The student knew he should phone 
ing in the clinic work, students seem to fall into four distinct groups. There are a few at the top of the clinic class who give promise of being able to take care of themselves anywhere, and dispose satisfactorily of any law business that comes to them. These are by no means necessarily the ones who win the highest grades in other courses. A second group includes men who are highly effective in some limited respect-such as briefing-but are not well rounded. They may be lamentably ineffective in meeting the public. They may have no ability to attract business because they do not know how to inspire confidence. Yet in their own field they may be very able. Following these come a group of more or less mediocre men who are able to pass examinations and can practice law but who do not show any particular aptitude and are not likely to bring any particular glory to the law school from which they graduate. At the tail end are those who, for one reason or other, are so obviously unprepared for practice that the seasoning process ought to be continued with respect to them for some time.

If a law school, by the clinic device, were to coordinate more successfully its functions of keeping men out of the profession and acting as a stepping stone for admission to it, two important results would follow: First, it would be possible, after exposing the class to conditions closely approximating general practice, to separate from the student group all the men below a certain standard and to delay their entrance until they demonstrated satisfactory proficiency, dependability, social viewpoint,

counsel for the defense and have a conference. Catching sight of the name of an attorney in his notes and not stopping to think who the attorney was, he phoned. After the conversation had proceeded for a space, the student suddenly realized that he was talking to opposing counsel. He had the good judgment to reveal nothing further. Opposing counsel realizing the mistake courteously referred the student to defense counsel.

In case No. 555 of the Duke Legal Aid Clinic the student in preparing an advisory brief for a public official forgot that the legislature had met in 1933 . So his brief failed to include any consideration of the most recent statute on the subject.

In case No. 599 of the Duke Legal Aid Clinic the student had been assigned the task of drawing a document. It should have been ready by a certain day. On the preceding day the student deposited a few pages of incomplete notes on the desk of the clinic secretary and announced that it was necessary for him to go home on his vacation.

More serious are the occasional cases arising in most clinics where a client's rights are lost through student negligence in filing papers.

These errors may be remedied with little trouble. Often they are symptoms of a mental attitude of the student. As such they deserve serious study. In a sense the student is the client of the law school and has reason to expect careful consideration of his fitness for the work he is to do. Failure to investigate his reactions to the normal events of a lawyer's life ushers him unprepared into a highly competitive situation. He should have at least a hint of what will confront him and of his ability to make headway with it.

See also for examples of attempts to deal with these student viewpoints, the minutes of meetings of the staff of the Duke Legal Aid Clinic. 
and the other characteristics of a good lawyer in active practice. Second, it would be possible to ascertain with increasing accuracy the limitations of a particular student and thus help him to find the special niche where he can do his most effective work. Failure on the part of the law school to provide these individualized facilities restricts definitely its usefulness to the community and to the student. The remedy suggested is no panacea, ${ }^{\text {II }}$ nor is the machinery of clinical instruction perfected to the desired point. Yet the field is one offering research opportunities of the same fascinating sort as those engaged in by workers in the physical sciences when they go forth on expeditions to distant and little known sections of the earth. Those who know most about the clinical method in law schools have confidence in the results already achieved; they believe that with care, patience and vision a much more effective instrument may be created. Its ultimate value will be to the community but the prestige for its creation will be to the law school.

II Additional efforts to meet this situation in its broadest terms include such devices as courses on the legal profession, student bar associations, practice courts. For a compilation of material on the subject see, Report of the Committee of the Duke Law Faculty on "Courses in the Profession of the Law" (I933). 